\title{
PLURALITAS AGAMA DALAM KELUARGA JAWA
}

\section{Agus Prasetyo}

SMA Al-Iman Temanggung, Temanggung, Jawa Tengah, Indonesia

\section{Info Artikel}

\section{Sejarah Artikel:}

Diterima Desember 2012

Disetujui Januari 2013

Dipublikasikan Maret 2013

\section{Keywords:}

plurality;

religion;

getas community.

\begin{abstract}
Abstrak
Dalam masyarakat Jawa terdapat pemahaman dan pemaknaan sendiri terhadap agama yaitu "agami ageming aji". Artinya apa pun agama yang dipeluk sama saja karena semua agama mengajarkan keselamatan. Oleh sebab itu menjadi sebuah fenomena menarik di kalangan masyarakat Jawa karena mereka cenderung lebih toleran dalam menyikapi perbedaaan dan keragaman beragama. Salah satu contoh masyarakat yang menghargai pluralitas agama adalah masyarakat Desa Getas Kaloran Temanggung. Tujuan penelitian ini adalah untuk menjelaskan tentang sejumlah keluarga yang dapat menerima pluralitas agama dan toleransi terhadap pluralitas agama dalam keluarga Jawa. Tulisan ini merupakan hasil penelitian yang menggunakan pendekatan deskriptif kualitatif. Subyek penelitian adalah masyarakat Desa Getas yang memiliki keragaman agama dalam keluarganya. Berdasarkan hasil penelitian dapat disimpulkan bahwa masyarakat Desa Getas dapat menerima pluralitas agama karena menurut mereka agama adalah urusan pribadi seseorang jadi tidak ada pihak yang dapat memaksakan suatu keyakinan kepada individu lain. Pluralitas agama tersebut tidak menimbulkan masalah berarti karena masyarakat memiliki derajat toleransi yang tinggi antar anggota keluarga, yang ditunjukkan melalui saling menghargai dan mengormati dan tidak mencampuri urusan keagamaan orang lain, serta saling membantu antar anggota keluarga untuk memperlancar kegiatan ibadah masing - masing.
\end{abstract}

\begin{abstract}
In Javanese community there is a specific principle on the meaning of religion, namely "agami ageming aji". This pilosophy means whatever religion people believe, it doesn't matter because they all teach salvation. This is an interesting phenomenon among the Javanese community because they tend to be tolerant in dealing with differences and diversity of religion that happen in one household. The objective of this article is to discuss the practices of religious tolerance found in a rural community of Getas, Kaloran, Temanggung Central Java. Techniques of data collection is done by interviews and observation. The study subjects were villagers of Getas, which has a diversity of religion in families. Based on the research results, it can be concluded that the villagers embrace a tradition of religious pluralism because they think religion is one's personal affairs so that no party can impose a conviction for another individual. The plurality of religion does not cause significant problems because the public has a high degree of tolerance among family members, which is demonstrated through mutual respect and attitude not to interfere in religious affairs of others, and mutual help among family members to facilitate the worship activities of their relatives.
\end{abstract}

(C) 2013 Universitas Negeri Semarang 


\section{PENDAHULUAN}

Masyarakat Jawa adalah masyarakat yang plural. Pluralitas masyarakat Jawa ini dapat dilihat dari bahasa yang digunakan, dari berbagai tradisi yang diadakan, dari bentuk rumah yang ditempati, dari keanekaragaman kuliner atau makanannya dan masih banyak lagi yang lainnya. Dari bahasanya setiap masyarakat Jawa banyak sekali logat-logat yang digunakan seperti logat Jawa pedalaman (masyarakat Jawa yang dekat dengan keraton), logat Pesisiran, logat ini digunakan oleh masyarakat yang bertempat tinggal di daerah pesisir, logat Banyumasan atau bahasa ngapak-ngapak, logat ini digunakan oleh masyarakat yang bertempat tinggal di daerah Banyumas (Banyumas, Purbalingga, Purwakarta, Cilacap Dan Banjarnegara). Bahasa Jawa tergolong ke dalam keluarga Hesperonesia dari keluarga Malaya-polinesia. Tradisi-tradisi yang dilakukan dalam masyarakat, bahkan setiap daerah berbeda-beda, hal seperti ini dikarenakan perbedaan kondisi geografis antara masyarakat pesisir dan pedalaman.

Pluralitas dalam masyarakat Jawa juga terjadi dalam aspek keagamaan. Banyak studi yang telah dilakukan mengenai religi masyarakat Jawa, salah satu yang banyak menjadi rujukan adalah studi Clifford Geertz di Jawa Timur yang menemukan bahwa masyarakat Jawa dalam aspek religinya dapat dikategorikan menjadi tiga varian yaitu Abangan, Santri, dan Priyayi (Geertz, 1982). Abangan adalah golongan masyarakat yang mencampurkan ajaran Islam dengan Animisme, Santri merupakan golongan Islam puritan yang menjalankan ajaran sesuai $\mathrm{Al}$ Qur'an dan hadist Nabi. Sementara priyayi adalah golongan masyarakat yang menjalankan praktik Islam yang bercampur dengan kepercayaan Hinduisme. Golongan Abangan dan Priyayi inilah yang kemudian banyak dilabeli dengan istilah Islam Jawa atau kejawen (Koentjaraningrat, 1994).

Agama dalam masyarakat Jawa jarang diperbincangkan dan jarang mempertanyakannya kecuali untuk memperoleh atau membuat KTP, SIM dan sebaginya (Woodward,1988; 1989; Hefner, 1987), ini dikarenakan dianggap kurang sopan. Dalam masyarakat Jawa agama juga tidak terlalu dipermasalahkan dikarenakan masyarakat Jawa terdapat pemahaman dan pemaknaan sendiri terhadap agama. "Agama ageming aji" apa pun agama yang dipeluk sama saja karena semua agama mengajarkan keselamatan. Pemaknaan yang kedua adalah dari kata "aji" yaitu dengan pengertian "ratu" bahwa agama yang dipeluk oleh Raja atau Ratu agama itulah yang dipeluk masyarakatnya (Damami, 2002). Tidak heran jika masyarakat Jawa dahulu berubah-ubah agamanya, dan terjadi perbedaan agama karena hal ini mengikuti dari keyakinan rajanya. Dalam masyarakat Jawa agama lebih nampak pada kelompok masyarakat santri (yaitu individu yang sepenuhnya telah melaksanakan dan menghayati nilai-nilai syariat Islam). Tetapi untuk kelompok di luar itu pemilihan agama bebas tergantung pemeluknya. Sebagaimana dikatakan Ibrahim, pluralitas keagamaan di Indonesia tidak saja ditunjukkan oleh keberagaman agama yang saat ini diakui negara ada 6 agama, namun pluralitas juga terjadi dalam satu agama yang terdiri dari berbagai aliran (Ibrahim, 2008).

Pluralitas agama merupakan hal yang aksiomatik dan tidak perlu dibantah lagi dan merupakan keniscayaan sejarah yang bersifat universal. Pluralitas agama harus dipandang sebagai bagian dari kehidupan manusia yang tidak dapat dilenyapkan tetapi harus disikapi. Pluralitas agama melahirkan benturan, konflik, kekerasan, dan sikap anarkhis terhadap penganut agama lain. Potensi ini disebabakan karena setiap ajaran agama memiliki aspek eksklusif berupa truth claim, yaitu pengakuan bahwa agamanya yang paling benar. Tuhan yang disembah, Nabi yang membawa wahyu, syari'at atau ajaran agama yang dimiliki dan diyakini sebagai yang paling benar. Konsekuensinya adalah agama lain dianggap tidak benar dan sesat. Dengan demikian, pluralisme menyimpan potensi positif dan negative dalam konteks hubungan manusia dan masyarakat. Upaya membangun common platform dengan perjumpaan dan dialog yang konstruktif dan berkesinambungan dengan agama lain merupakan tugas manusia yang perennial dan abadi (Attabik dan Sumiarti,2008;2-3). 
Pluralitas agama juga terdapat dalam keluarga mayarakat Desa Getas, Kecamatan Kaloran, Kabupaten Temanggung. Desa Getas adalah sebuah desa yang terletak di Perbukitan. Luas daerahnya mencapai 815 ha dengan daerah yang demikian luas Desa Getas terbagi menjadi 10 (sepuluh) pedukuhan, dengan jumlah penduduk 4.045 orang. Desa Getas kehidupan beragama penduduknya sangat rukun, terbukti sampai saat ini tidak ada satu masalah yang bersumber pada masalah agama. Di Desas Getas terdapat 4 agama besar yang diakui di Indonesia yaitu Islam, Kristen, Katholik dan Budha.

Berdasarkan latar belakang di atas, maka tulisan ini akan membahas dua hal yakni; pertama, bagaimana alasan dari sejumlah keluarga untuk dapat menerima pluralitas agama berdasarkan kasus masyarakat di Desa Getas Kecamatan Kaloran Kabupaten Temanggung. Kedua, toleransi yang dikembangkan dalam menyikapi pluralitas agama dalam keluarga Jawa di desa tersebut.

\section{METODE PENELITIAN}

Penelitian ini menggunakan pendekatan deskriptif kualitatif. Fokus penelitian ini adalah latar belakang tejadinya pluralitas agama dalam keluarga Jawa dan toleransi pluralitas agama dalam keluarga Jawa. Adapun subjek dalam penelitian ini adalah keluarga yang di dalamnya terdapat lebih dari satu agama, keluarga yang agamanya hanya satu, tokoh atau pemuka agama, aparatur pemerintah (Kepala Desa, Carik, Kasi Kesra). Untuk memperoleh data dalam penelitian ini, teknik-teknik yang telah digunakan diantaranya observasi (pengamatan lapangan), wawancara (interview) serta dokumentasi.

\section{HASIL DAN PEMBAHASAN}

Secara adminitrasi desa Getas masuk kedalam wilayah Kecamatan Kaloran, Kabupaten Temanggung. Jarak Desa Getas dari Kota Kecamatan 5 Km, jarak Desa Getas dari kota Kabupaten $30 \mathrm{Km}$. Desa Getas memiliki luas wilayah 815 ha dengan jumlah penduduk 4.045 orang, Desa Getas terletak di daerah perbukitan yang dikelilingi oleh gunung yaitu Gunung Ungaran, Gunung Sindoro dan Gunung Sumbing dengan keadaan topografi yang tereletak di lereng gunung dan berbukit menjadikan udara di Desa Getas berhawa sejuk bahkan cenderung dingin.

Desa Getas terbagi kedalam 10 dusun yaitu Porot, Cendono, Kemiri, Banyuurip, Selorejo, Krecek, Pringapus, Ngalarangan, Gletuk dan Getas. Setiap dusun satu dengan dusun yang lain jaraknya cukup jauh yaitu sekitar 1-3 Km dan dipisahkan oleh lahan pertanian. Setiap dusun dipimpin oleh Kepala Dusun (Kadus) yang selanjutnya Kepala Dusun (Kadus) bertangung jawab kepada Kepala Desa.

Meskipun terletak di daerah perbukitan, warga desa Getas dalam hal pendidikan tidak kalah denga desa yang lain. Kesadaran akan pentingnya pendidikan mulai tumbuh pada masyarakat. Banyak orang tua yang memperhatikan pendidikan anak-anaknya bentuk perhatian orang tua terhadap pendidikan anak terlihat dari jumlah sara prasarana yang ada. Dapat dikatakan sarana prasarana lengkap dari play group sampai SMA.

Karena sebagian besar wilayah Desa Getas merupakan daerah pertanian maka mata pencaharian penduduknya di bidang pertanian yaitu petani ladang walaupun ada sebagian yang menggarap sawah, tetapi para penggarap sawah terbentur kebutuhan air. Meskipun terletak di lereng gunung untuk kebutuhan air para warga masih kesulitan, untuk mendapat air masyarakat harus mencari air sampai kesumber mata air dengan jarak $3 \mathrm{~km}$. Untuk sekarang ini penduduk dapat bernafas lega masyarakat tidak usah menuju ke sumber mata air karena sekarang air sudah dialirkan menggunakan paralon dan ditampung di bak penampungan air yang berukuran besar jadi dapat digunakan untuk semua penduduk dan dalam jangka waktu yang cukup lama usaha ini dilakukan perkelompok jadi warga membentuk kelompok untuk mendapatkan air. Itulah sebabnya para penduduk memilih bertani ladang, tanaman yang ditanam adalah Jagung, kacang tanah, ketela pohon, ketela rambat, kopi, pisang, cabe dan masih banyak yang lainnya.

Penduduk Desa Getas juga ada yang 
Tabel 1.Penduduk Desa Getas berdasarkan Agama

\begin{tabular}{lllll}
\hline No & \multicolumn{1}{r}{ Agama } & \multicolumn{1}{r}{ Jumlah } & Laki-laki & Perempuan \\
\hline 1. & Islam & 1.690 & 877 & 813 \\
2. & Kristen & 826 & 405 & 421 \\
3. & Budha & 1.503 & 755 & 748 \\
\hline
\end{tabular}

Sumber : Monografi Desa Getas tahun 2010

berprofesi sebagai peternak, hewan ternaknya antara lain adalah kambing, sapi, ayam dan babi. Untuk memenuhi kebutuhan pakan ternak penduduk mengambil dari kebun untuk kambing dan sapi sedangkan untuk ternak ayam masyarakat membeli kepasar terdekat Pasar Sumowono dan Pasar Temanggung. Khusus untuk ternak babi masyarakat mendatangkan dari Ambarawa dan Salatiga dengan cara memesan terlebih dahulu. Untuk penjualan peternak menjual kepasar hewan untuk sapi dan kambing, untuk ayam masyarakat menjual kepada tetangga atau ke pasar, untuk babi masyarakat jual ke Kopeng, Salatiga.

Kehidupan beragama di Desa Getas terjalin dengan rukun, dan boleh dikatakan tidak ada konflik atau pertikaian antara warga masyarakat yang bersumber dari agama dan antara tempat ibadah agama yang satu dengan yang lain berdekatan. Kerukunan tersebut dapat terjadi karena masyarakat Getas mempunyai pandangan atau pemikiran bahwa semua agama itu sama saja, karena semua agama mengajarkan kebaikan atau dalam istilah masyarakat Getas "agamaku agamaku agamamu agamamu" artinya kita tidak usah memikirkan agama oarang lain yang penting kita menjalankan kehidupan sesuai ajaran agama masing-masing.

Pluralitas agama di Desa Getas juga ditunjukkan dengan keberadaan rumah ibadah dari berbagai agama dengan jumlah yang berimbang. Terdapat 8 masjid, 7 buah gereja dan 10 vihara di Desa Getas. Demikian pula dengan komposisi jumlah penduduk seperti yang diperlihatkan dalam monografi desa Getas pada Tabel 1.

Data pada Tabel 1. memperlihatkan bahwa berdasar komposisi penganut agama, pluralitas umat beragama di Desa Getas memang sangat kentara karena jumlah penganut agama yang berimbang, tidak ada mayoritas maupun minoritas. Salah satu aspek kehidupan sosial yang menarik di Desa Getas adalah tentang pluralitas agama dan kerukunan umat beragama. Pluralitas agama dan kerukunan umat beragama tidak hanya terjadi pada tingkat masyarakat, tetapi terjadi pada keluarga. Di Desa Getas banyak dijumpai keluarga yang anggotanya memeluk berbagai agama. Namun meskipun beragam, menurut warga jarang terjadi konflik yang disebabkan karena keragaman agama tersebut. Hal serupa juga disampaikan oleh Kepala Desa Getas yaitu Bapak Dwiyanto (28 tahun) berikut ini :

selama ini di masyarakat tidak pernah terjadi pertikaian atau konflik yang bersumber pada masalah agama. Karena masyarakat saling menghormati dan mengahargai kepercayaan dan keyakinan masing.

Jika ditelaah lebih jauh, harmoni yang berlangsung di Desa Getas sejalan dengan apa yang di kemukakan oleh Damami (2002) bahwa bagi masyarakat Jawa agama dipahami sebagai "ageming aji" yaitu bahwa agama merupakan pedoman hidup yang pokok, artinya bahwa agama apa saja mengajarkan atau mengandung ajaran yang serba baik untuk keselamatan dan kesejahteraan hidup masyarakat di dunia ini apa pun agama yang dipeluk sama saja karena semua agama mengajarkan keselamatan (Damami, 2000: 32).

Toleransi beragama yang besar di kalangan masyarakat Jawa juga dijelaskan oleh Roibin (2008) yang mengemukakan bahwa praktek toleransi dalam masalah kepercayaan pada masyarakat Jawa merupakan salah satu hal yang menjadi kebanggaan kultural masyarakat Jawa. Toleransi orang Jawa tersebut terbentuk karena berbagai latar dan aspek, baik aspek psikologis, politis dan historis. 
Dalam tataran aktivitas, kerukunan umat beragama juga terlihat ketika salah satu kelompok umat beragama sedang punya keperluan entah membangun tempat ibadah, melaksanakan kegiatan tertentu, memperingati hari-hari besar agama dan kegiatan yang lain orang di luar agama tersebut ikut membantu jika diminta tolong. Keikut sertaan ini bisa berupa sumbangan dana dan material, dan melakukan tanpa paksaan.

Menurut salah satu tokoh agama Islam Bapak Narudin untuk menjaga kerukunan umat beragama adalah dengan cara menghimbau kepada jemaatnya jangan ada rasa fanatik, sebab rasa fanatik akan menimbulkan perasaan-perasaan atau tindakan yang tidak baik. Berikut adalah wawancara dengan Bapak Narudin:

Ya saya berpesan kepada umat supaya jangan ada pikiran fanatik, karena pikiran fanatik akan memunculkan rasa dan tindakan yang berdampak buruk. Biarlah agama mereka menjadi agama mereka, karena agama mereka adalah pilihan mereka. Kita jalankan saja agama kita.

Dari kalangan agama atau tokoh agama Budha menyatakan bahwa selama ini tidak pernah terjadi pertikaian atau konflik yang bersumber pada masalah agama. Karena dalam agama Budha sendiri juga dilakukan beberapa uasaha supaya tidak terjadi perpecahan atau pertikaian antara umat beragama yang satu dengan umat agama yang lain. Untuk agama Budha sendiri sosialisasi dilakukan dengan berbagai cara dan di berbagai pertemuan. Seperti sembayangan di Vihara, Pegurusan Vihara, Sekolah Minggu, Diskusi, dan melakukan gotong royong baik dengan sesama umat Budha maupun dengan uamat beragama yang lain.

Khusus untuk gotong royong dilakukan dengan membangun Vihara, Tempat ibadah yang lain (Gereja, Masjid) dan membuat sarana umum, seperti jalan, salauran air, membuat saluaran air bersih untuk kepentingan rumah tangga dan membangun rumah tempat tinggal. Disamping itu dalam ajaran agama Budha juga menganjurkan umatnya dalam menyelesiakan permasalahan tanpa pertikaian dengan kata lain mengharamkan pertikaian. Sebab ajaran Budha Gautama adalah ajaran kasih.

Berikut adalah penuturan dari salah satu tokoh agama Budha yaitu Bapak Suryanto dalam sebuah wawancara.

Selama ini tidak ada pertikaian dalam
warga masyarakat khususnya umat Budha
yang bersumber pada masalah agama, ka-
rena ajaran Budha sendiri yang notabene
dari Sang Budha Gutama adalah ajaran
kasih, jadi tidak menganjurkan umatnya
untuk bertikai. Dalam menyelesaikan ma-
salah dilarang keras dengan cara perteng-
karan apa lagi dengan umat agama yang
lain. Penyampaian ajaran ini ya dilakukan
dalam sembayangan umum di Vihara Se-
kolah Minggu bagi anak-anak, dilakukan
diskusi untuk mencari jalan keluar dalam
memecahkan suatu masalah.

Dalam agama Kristen juga senada dengan agama-agama yang lain. Pemuka atau tokoh agamanya menghimbau jemaatnya supaya hidup berdampingan dengan umat agama yang lain, supaya terjadi kerukunan umat beragama dan lingkungan yang kodusif tanpa ada masalah antara warga yang satu dengan warga yang lainnya. Berikut ini tuturan Bapak Pdt. Filimon dalam wawancara dengan penulis.

Selama ini tidak ada pertikaian anatar warga masyarakat yang bersumber pada masalah agama. Karena dalam ajaran agama Kristen yang di ajarkan oleh Yesus Kristus atau Isha Alaisalam adalah ajaran kasih. Jadi orang yang percaya pada Yesus Kristus Atau Isha Alaisalam atau orang Kristen hidupnya harus penuh kasih. Untuk menunjukan bahwa di dalam orang Kristen ada kasih salah satu caranya adalah dengan hidup berdampingan dan tanpa pertikaian dengan umat beragama yang lain. Jadi, kehidupan umat Kristen semacam bersaksi atau memperlihatkan tentang ajaran agama melalui tingkah laku dalam kehidupan keseharian. Penyampaian ajaran ini dilakukan pada saat persekutuan umum pada hari minggu, persekutuan di hari-hari lain, sekolah minggu bagi anakanak. 
Pluralitas yang muncul di Desa Getas tidak hanya sebatas dalam tataran kehidupan bermasyarakat, bahkan pada tingkatan keluarga juga terjadi pluralitas agama. Seperti dalam keluarga Bapak Badri Purwanto misalnya. Dalam keluarga ini terdapat tiga agama sekaligus yaitu Budha, Islam Dan Kristen. Kondisi keluarga ini seperti keluarga lainnya yang hanya terdapat satu agama. Hubungan bapak selaku kepala keluarga dengan anggota keluarga terjalin harmonis dan mesra, begitu juga dengan istri, ibu dan anak anaknya. Keluarga ini menyadari bahwa agama adalah hak asas seseorang jadi tidak dapat memamksakan agama atau keyakinannya kepada seesorang. Mereka saling menghargai satu dengan yang lain. Pluralitas agama dalam keluarga tersebut seperti yang dikemukakan oleh Bapak Riyanto menjelaskan kondisi keagamaan dalam keluarganya sebagai berikut:

Riyen Simbah bapak kaliyan ibu kulo Budha sedanten. Lajeng kula mlebet Islam, semah kulo Islam lan anak-anak kula waune nderek semah kulo (Islam) lajeng sak niki anak-anak kula mlebet Kristen, nek pemangih kulo soal agami niku mboten saget di paksake, dadi kulo geh ben semah kalian anak-anak benten agamanipun kalian kulo.

(Dulu kakek nenek, bapak dan ibu saya Islam semua. Lalu saya masuk agama Budha, istri saya Islam dan dulu anak-anak saya ikut istri saya, tetapi sekarang mereka (anak-anak) masuk agama Kristen. Menurut pemahaman saya soal agama itu tidak dapat dipaskan, jadi ya biar saja istri dan anak-anak saya berbeda agama.)

Meski terjadi perbedaan agama dalam keluarga sosialisasi nilai-nilai budaya atau yang berlaku dalam masyarakat tetap berjalan. Karena keluarga ini sadar meski terjadi perbedaan agama tetapi komunikasi antar anggota keluarga harus tetap berjalan. Salah satunya adalah dengan cara sosialisasi kepada anak. Sosialisasi yang tejadi dalam keluarga Bapak Badri dilakukan dengan cara memberi nasihat-nasihat dan memberi keteladanan perilaku. Artinya sebelum ayah atau anggota keluarga yang lainnya meyuruh atau menyarankan kepada anggota keluarga untuk melakukan sesuatu maka orang tua harus melakukan dulu apa yang telah diperintahkan. Contoh jika orang tua menyuruh anaknya rajin beribadah maka orang tua harus rajin beribadah terlebih dahulu.

\begin{abstract}
Keluarga mriki maringi sesuluh lewat contoh prilaku ing paditenan kaliayan maringi wejangan dateng anak. Sak derange kulo ngandani putro uatawi anak kulo teladan ing prilaku kolu, koyoto sadarenga kulo ngengken anak kulo supados taat lan sregep nagabekti, kulo kedah taat lan sregep nagabekti menurut kapitayan kulo, nek wejangan atawi nagdani anak kulo kandani supados mbesuk nek sampun omah-omah utawi sampun keluarga piyambak supados ing keluarga niku enten setunggal agami tok.
\end{abstract}

(memberikan sosialisasi lewat contoh prilaku, misal jika saya menyuruh anak saya supaya rajin beribadah ya, saya harus rajin beribadah dulu, jika lewat kata-kata saya berbicara kepada anak-anak saya jika nanti sudah berkeluarga dalam keluarganya cukup satu agama saja.)

Dalam hal toleransi keluarga ini menyadari akan perbedaan yang terjadi. Mereka saling memperhatikan antara sesama anggota keluarga, apabila salah satu anggota keluarga lain yang berbeda agama melakukan kegiatan agama keluarga yang lain juga ikut atau menghargai. Misal dalam keluarga ini ada yang beragama Islam, jika yang beragama Islam melakukan kegiatan agama seperti ibadah puasa dan Idul Fitri anggota keluarga yang lain ikut membantu. Dalam membantu melaksanakan ibadah puasa dengan cara tidak makan di depan anggota keluarga yang sedang berpuasa atau ikut menyediakan hidangan berbuka dan sahur. Dalam melaksanakan Idul Fitri anggota keluarga yang berbeda agama ikut menyiapkan kebutuhan yang diperlukan dan yang pertama dan terutama memberikan ucapan selamat. Begitu juga jika yang beragama Budha melaksanakan Waisak anggota keluarga yang berbeda agama memberikan ucapan selamat dan ikut merayakan, dengan ikut ke Vihara. Untuk yang beragama Kristen juga begitu jika anggota keluarga Kristen merayakan Natal 
maka anggota keluarga yang berbeda agama memberikan ucapan selamat dan ikut ke Gereja

Pada dasarnya dalam keluarga ini menerima adanya perbedaan agama dalam keluarga dan saling menghargai hak asasi anggota keluarga. Sikap saling menghargai ini ditujukan pada tidak dipaksakannya anggota keluarga untuk memeluk salah satu agama. Keharmonisannya juga terlihat pada saat salah satu anggota keluarga melasanakan perayaan agama, anggota keluarga yang berbeda agama juga membaur menjadi satu yaitu ikut membantu. Karena mereka berfikir agama adalah masalah pribadi dan pilihan seseorang jadi tidak ada seseorang yang dapat memaksa untuk memeluk agama tertentu.

Kondisi yang sama juga terjadi pada keluarga Bapak Rusmanto, di dalam keluarga ini terdapat agama Budha dan Islam. Meskipun terdapat perbedaan agama dalam keluarga, tetapi hubungan sesama anngota keluarga berjalan dengan harmonis tanpa ada masalah yang muncul khusunya masalah perbedaan keyakinan atai agama.

Gih saling ngormati mawon, sebabe masalah agami niku kan masalah pribadi dadi kulo lan sinten mawon mboten saget ngutik-ngutik bab kapitayan atawi agamai.

(ya saling menghormati saja, sebab masalah agama itu kan masalah pribadi jadi saya dan siapapun tidak dapat membahas atau memaksa persoalan kepercayaan atau agama.)

Masalah pluralitas menurut Machasin (2001:66) bukanlah barang baru bagu bangsa Indonesia. Masyarakat Indonesia sudah berabad-abad terbiasa dengan keragaman. Seperti yang dikemukakan Bapak Suseno bahwa semua agama itu mengajarkan toleransi dan perdamaian dan tidak membenarkan kebencian dan tindak kekerasan terhadap umat beragama serta gedung-gedung ibadatnya. Dari berbagai pengertian agama dan pernyataan ini menegaskan bahwa seseorang bebas memilih atau memeluk agamanya sesuai dengan keyakinanya, tanpa adanya suatu tekanan atau paksaan dari pihak lain. Hal tersebut ternyata memang telah dipraktekkan secara alami oleh warga masyarakat di Desa Getas.

Pluralitas agama dan kerukunan sudah menjadi suatu hak yang mendarah daging bagi masyarakat Desa Getas. Warga masyarakat saling menghargi dan saling menjaga sikap atau perkataan supaya tidak terjadi pertikaian antar umat beragama. Sikap dan perkataan warga masyarakat ditunjukan dalam sikap tidak memaksakan suatu agama dan saling menghormati antar pemeluk agama, ketika pemeluk agama lain merayakan hari besar agama pemeluk yang agama lain juga ikut mengucapkan selama dan membantu supaya perayaan hari besar agama berjalan dengan lancar, dan kehidupan keluarga berjalan dengan rukun. Begitu juga pada tingkatan keluarga mereka saling membantu, jika ada salah satu anggota keluarga yang berbeda agama mereka membantu menyiapkan segala sesuatunya supaya anggota keluarga tersebut dapat memperingati hari besar agamanya.

Pemahaman dan pemikiran ini yang dipakai atau dianut oleh beberapa keluarga yang di dalam keluarga tersebut terdapat perbedaan agama. Salah satunya adalah keluarga Bapak Sarwono, di dalam keluarga ini terdapat tiga agama yaitu Islam, Kristen dan Budha. Dalam keluarga ini saling hidup berdampingan tanpa adanya suatu masalah. Seperti yang tertulis dalam hasil wawancara berikut ini.

Gih saling ngormati mawon, sebabe masalah agami niku kan masalah pribadi dadi kulo lan sinten mawon mboten saget ngutik-ngutik bab kapitayan utawi agamai.

(ya saling menghormati saja, sebab masalah agama itu kan masalah pribadi jadi saya dan siapapun tidak dapat membahas atau memaksa persoalan kepercayaan atau agama.)

Tidak hanya pluralitas agama yang menjadi ciri bagi masyarakat Desa Getas tetapi juga masalah kerukunan umat beragama yang terjalin sangat harmonis. Ini semua terjadi karena adanya kerjasama antara pamong desa dan tokoh agama setempat. Juga adanya rasa saling menghormati dan meng- 
hargai agama dan keyakinan masing-masing. Kondisi ini dikarenakan bahwa masyarakat sadar masalah agama adalah masalah pribadi dan pilihan pribadi.

Seperti dalam keluarga Bapak Sarwono misalnya. Dalam keluarga ini terdapat tiga agama sekaligus yaitu Budha, Islam Dan Kristen.

Dahulu saya beragama Budha terus saya dan istri masuk agama Kristen anak saya dapat suami orang Islam, kalau teman yang dalam keluarganya terdapat perbedaan agama ada, terus kalau pernah atau tidak membaca buku tentang pluralitas agama tidak pernah. Bagi kami atau saya sendiri masalah agama itu adalah masalah pribadi dan pilihan seseorang jadi saya tidak dapat memaksakan karena itu adalah sudah menjadi pilihannya.

Mengenai masalah toleransi antar anggota keluarga, Bapak Sarwono menjelaskan bahwa dalam keluarganya saling membantu agar setiap anggota keluarga dapat menjalankan ibadah masing - masing dengan lancar, seperti penuturan berikut:

Kami di sini saling membantu dalam melaksanakan ibadah dalam arti lain toleransi kami junjung tinggi misal ibu saya akan melaksanakan Waisak ya saya mengantar sampai ke Vihara dan jika saya diundang saya ikut masuk dan ketika anak saya menjalankan ibadahnya seperti Puasa ya kami ikut membantu dengan cara menyiapkan hidangan Buka Puasa dan Sahur dan kami saling memberi selamat jika ada anggota keluarga yang berbeda agama yang sedang mejalankan ibadah atau merayakan hari besar agamanya.

Kondisi yang terjadi pada masyarakat di Desa Getas juga sejalan dengan apa yang dikemukaan oleh Muhamad Damami bahwa agama itu sama saja jadi ingin masuk agama saja bebas. Fakta ini didukung dengan pengaukuan yang di samapaikan oleh Keluarga Bapak Badri Purwanto beliau mengatakan:

Masalah benten agami kulo gadah pemahaman masalah agami niku urusane dewedewe, sedoyo agama niku sae podho-podho nagjerke kesaean. Datos kulo mboten saget mekso semah utawi anak kulo supados do setunggal kapitayan.

Dalam keluarga di desa Getas yang mengalami pluralitas agama juga menerapkan dua sikap toleransi di atas. Untuk sikap toleransi yang ditunjukan melalaui perbuatan antara lain saling membantu anggota keluaga yang berbeda agama, saling tolong menolong atau saling membantu di dalam keluarga yang berbeda agama terlihat disaat salah satu anggota keluarga yang berbeda agama sedang menjalankan ibadahnya atau sedang memperingati hari besar agama, anggota keluarga yang berbeda agama tidak lepas tangan anggota keluarga yang lainnya saling membantu semisal mempersiapkan apa yang diperlukan dalam menjalankan ibadahnya atau memperingangati hari besar agama. Sperti misal di dalam keluarga Bapak Badri dan Bapak Sarwono.

Oh tentu tidak kami di sini saling membantu dalam melaksanakan ibadah dalam arti lain toleransi kami junjung tinggi misal ibu saya akan melaksanakan Waisak ya saya mengantar sampai ke Vihara dan jika saya diundang saya ikut masuk dan ketika anak saya menjalankan ibadahnya seperti puasa ya kami ikut membantu dengan cara menyiapkan hidangan buka puasa dan sahur.

Di dalam penelitian ini terdapat beberapa contoh kasus keluarga yang mengalami pluralitas agama yaitu keluarga Bapak Badri Purwanto. Dalam keluaga ini terdapat tiga agama yaitu Islam, Budha dan Kristen. Menurut penuturan Bapak Badri Purwanto mengapa dalam keluarganya terdapat tiga agama adalah terjadi perpindahan agama atau perubahan agama. Dahulu sebelum Bapak Badri menikah dengan istrinya beragama Islam berhubung menurut peraturan pernikahan di Indonesia menikah harus satu agama maka pada tahun 1986 atau pada usia 23 tahun Bapak Badri Purwanto pindah keagama Budha kemudian sebulan kemudian pindah lagi ke agama Islam, dapat dikatakan perpindahan agama ini hanya untuk formalitas persyaratan menikah. Sedangkan anaknya dahulu sebelum ikut Kegiatan PPA 
(Proyek Pengembangan Anak) beragama Islam, setelah itu karena terbiasa ikut kegiatan PPA yang berlatar belakang agama Kristen maka kedua anaknya masuk dalam agama Kristen kepindahan agama anak-anaknya ketika berumur 9 (sembilan) tahun.

Meskipun keluarga ini mengalami pluralitas agama tetapi hubungan keluarga ini tetap harmonis karena antar anggota keluarga yang berbeda agama saling menghormatai dan bertoleransi baik secara perbuatan maupun perkataan. Sikap toleransi ini ditunjukan ketika salah satu anggota keluarga yang berbeda agama merayakan dan mejlalankan ibadah agama. Misal ketika Ibu atau istri dari Bapak Badri Purawanto menjalankan ibadahnya atau memperigati hari besar agama anggota keluarga lainnya mengatar ke Vihara baik itu suaminya maupun anaknya dan mereka memberi ucapan selamat ketika memperingatai hari besar agama. Begitu juga saat Bapak Badri Purawanto sedang menjalankan ajaran agama anggota keluarga yang lain ikut membantu semisal saat Bapak Badri Purawanto menjalankan ibadah puasa istrinya ikut menyiapkan hidangan buka dan sahur dan angota keluarga lain yang berbeda agama menghormatinya dengan cara tidak makan atau minum di depan Bapak Badri Purawanto yang sedang berpuasa.

Toleransi antarumat beragama ini tidak lepasa dari peran serta pemuka agama. Antar pemuka agama yang satu dengan yang lain terjadi hubungan yang harmonis. Hal ini dikarenakan masih ada hubungan keluarga antara pemuka agama contoh pemuka agama Kristen masih memiliki hubungan keluarga dengan pemuka agama Islam. Untuk pemuka agama Budha klarena rumahnya berdekatan dengan pemuka agama yang lain sehingga mempermudah hubungan interaksinya.

\section{SIMPULAN}

Berdasarkan hasil penelitian dan pembahasan, dapat disimpulkan bahwa warga Desa Getas dapat menerima pluralitas agama karena menurut pemahaman warga desa Getas agama itu adalah urusan pribadi seseorang jadi tidak ada pihak yang dapat me- maksakan suatu keyakinan kepada individu lain, dengan pemikiran ini menyebabkan terjadinya pluralitas agama dalam masyarakat. Dengan demikian masyarakat Desa Getas meyakini agama sebagai urusan yang masuk dalam domain privat, bukan urusan publik sehingga tidak layak untuk diperdebatkan dalam kehidupan bermasyarakat. Pandangan tersebut memang telah menjadi pandangan tipikal khas yang dimiliki oleh masyarakat Jawa bahwa toleransi menjadi sebuah keunggulan budaya yang dibanggakan oleh masyarakat Jawa. Pluralitas tersebut tidak menyebabkan perpecahan dalam keluarga karena mereka sangat sadar untuk memisahkan antara urusan agama yang bersifat privat dengan urusan di luar agama yang bersifat publik atau sosial.

\section{DAFTAR PUSTAKA}

Adnan, Z. 1990. State and Civil Society in Indonesia. Clayton, Victoria: Centre Southeast

Al-Qurtuby, S. 2001. Arus Cina-Islam-Jawa: bongkar sejarah atas peranan Tionghoa dalam penyebaran agama Islam di Nusantara abad XV \& XVI. Salatiga: Inspeal Press.

Brata, N. 2010. Konflik Menurut Orang Jawa. Jurnal Komunitas.2(1):15-25

Damami, M. 2002. Makna Agama Dalam Masyarakat Jawa. Yogyakarta: LESFI

Dhofier, Z. 1980. The Pesantren Tradition: A Study of the Role of the Kyai in the Maintenance of the Traditional Ideology of Islam in Java. Canberra: Australian National University

Fox, J. 1991. Ziarah Visits to the Tombs of the Wali, the Founders of Islam on Java. Canberra: Australian National University

Geertz, C. 1971. Islam observed: Religious development in Morocco and Indonesia. Chicago: University of Chicago Press.

Hefner, R.W. 1987. Islamizing Java? Religion and Politics in Rural East Java. The Journal of Asian Studies. 46 (3): 533-554

Hefner, R.W. 1987. The political economy of Islamic conversion in modern East Java. Princeton: Princeton University Press.

Ibrahim, R. 2008. Pendidikan Multikultural: Upaya Meminimalisir Konflik dalam Era Pluralitas Agama. Universitas Islam Indonesia. Jurnal El Tarbawi (Jurnal Pendidikan Islam). 1 (1): 100110 .

Koentjaraningrat. 1994. Kebudayaan Jawa. Jakarta: Balai Pustaka.

Ricklefs, M. 1991. Islam in the Indonesian social context. Monash: Monash Asia Institute.

Roibin.2008. Mitologi Religius dan Toleransi Orang Jawa. UIN Malang. Jurnal El Harakah. 10 (1): 
Agus Prasetyo / Komunitas 5 (1) (2013) : 64-73

10-20.

Saksono, W. 1995. Mengislamkan tanah Jawa: telaah atas metode dakwah Walisongo. Bandung: Mizan.

Tabik dan Sumiarti. 2008. 'Pluralisme Agama: Studi Tentang Kearifan Lokal di Desa Karangbenda Kecamatan Adipala Kabupaten Cilacap'. Jurnal Peneltian Agama.9(2):271-291.
Woodward, M. 1988. The" Slametan": Textual Knowledge and Ritual Performance in Central Javanese Islam. History of Religions. 28 (1), : 54-89

Woodward, M. 1989. Islam in Java: normative piety and mysticism in the Sultanate of Yogyakarta. Arizona: University of Arizona Press. 